\title{
The consequences of an open labour market in a closed product market in the economic environment of European professional football
}

\author{
Trudo Dejonghe ${ }^{\dagger}$ and Wim Van Opstal ${ }^{\dagger \dagger}$
}

December 2008

\begin{abstract}
Ever since the Bosman case opened the labour market for players in European professional football, competitive balance has reduced in favour of the Big 5 leagues (England, Spain, Italy, Germany and France). In this article we show that changing structures towards an open labour market in a closed product market resulted in a migration of player talents towards the major leagues and teams and in a competitive disadvantage for the smaller market leagues and their teams. Next to a theoretical argumentation, we provide empirical evidence and assess future options for the structure of European professional football.
\end{abstract}

JEL Classification Codes: J61, L52, L83

Keywords: Bosman case, competitive balance, international labour mobility, professional team sports, stepping stone league

${ }^{\dagger}$ Lessius Hogeschool (KULeuven) Department Business Science, Korte Nieuwstraat 33, 2000 Antwerpen, Belgium, Trudo.dejonghe@lessius.eu

${ }^{\dagger}$ Higher Institute for Labour Studies - Catholic University of Leuven 


\section{Introduction}

Sports success in European football is becoming concentrated in some countries. The bigger market leagues such as England, Spain, Italy and in a lesser degree Germany and France, also known as the Big 5, are gradually dominating international competitions. Some former historical major teams such as Ajax Amsterdam, RSC Anderlecht, Celtic Glasgow or FC Porto to mention some are relegated to secondary teams on the international forum. In this article we show that changing structures towards an open labour market in a closed product market resulted in a migration of player talents towards major leagues and teams and in a competitive disadvantage for smaller market leagues and their teams.

Many sports economist, however, argued in the nineties that the changing conditions in the labour market would have no impact on competitive balance ${ }^{3}$ and the distribution of player talent. They used arguments taken from US cases but neglected the typical structure of European professional football. These same sports economists argued later on that an European Football League with characteristics of the American professional sports league model would be the solution for all inequalities and concentration tendencies in Europe. On the other side of the spectrum, other sports economists argued that an American model with cross-subsidization is not compatible with the European approach towards sports and the introduction of an open labour market will result in a concentration of talent into the Big 5 as well as more recently in Eastern European leagues with "new money". They stand for a limitation of the openness of the labour market. Examples of this kind of initiatives are the "Home grown rule" or the " $6+5$ rule". A solution in between is the creation of regional leagues such as a Bene League or a Royal League (Denmark-Norway-Sweden) that may be able to compete with the Big 5 .

In this article we investigate the consequences of an open labour market in a closed product market. First we argue that in win maximization competition between leagues a concentration of player talent in the major leagues occurs. Empirical evidence on the performance in UEFA competitions such as the Champions League and UEFA cup and the migration of players selected for their national team in World Cup finales will confirm that competitive balance between leagues is declining. In other words the opening of labour market in a closed product market had a divergent effect on professional football in Europe.

\section{From closed to open labour market}

On December 15th 1995 the European Court of Justice in Luxemburg declared in the Bosman Case that the existing transfer system in the EU was in conflict with article 39 of the EC-Treaty ${ }^{4}$. Carl Otto Lenz, one of the court's influential advocates-general, called for the abolishment of the transfer system in football, on the ground that it "infringes the player's freedom of movement" for one club to demand payment from another before permitting the player to change employers. He added that the European Football Federation, UEFA, had no right to limit the number of foreign players that a team can put on the pitch. A general principle of EU law is that discrimination on grounds of nationality regarding EU citizens is illegal and that all citizens are allowed to work in other EU countries under the same conditions. The consequence of this arrest was that all players at the end of their contract became free agents. The result of this arrest was that clubs lost their monopsony power over players. On the 
contrary market power went to those players who could sell their talents to the team that offered the highest wages. In combination with this power shift, European football faced the elimination of the limitation of the number of foreign players which resulted in a massive migration of player talent. The Bosman case made factor mobility of labour possible and resulted in a reallocation of player talent.

The arguments of the football federations and UEFA to defend the existing transfer system were that transfer fees were a form of revenue sharing and remuneration of assets and that without these financial compensations clubs would eradicate youth development. Parrish \& McArdle (2004) notice that Otto Lenz foresaw in his verdict alternative possibilities such as revenue sharing and salary cap to maintain existing or even increase competitive balance. The problem was that this kind of crosssubsidization would be difficult to implement in the structures of European football. Moreover, UEFA and the national federations never took these alternatives into concern and defended their monopsony rights. The academic world, however, countered their arguments on the probability of concentration of player talent and decreasing competitive balance. Késenne (1998a) indicated that North-American sports economists such as Noll (1974), Scully (1989) and Quirk \& Fort (1992) analyzed the elimination in 1976 of the "reserve clause" in the US, a system comparable to the transfer system before Bosman, in the Major League Baseball (MLB). There conclusion, based on existing theoretical and empirical studies, was that professional leagues in US would benefit if limitations on freedom of players movement were eliminated.

The distribution of player talent in a market equilibrium is according to Quirk \& Fort (1992) related to the market size of the clubs. Their central argument came from Rottenbergs (1956) article that anticipated on the in 1960 published Coase theorem. This famous article by Nobel Laureate Ronald Coase argued that "with zero transactions costs, private and social costs will be equal". In other words, in a world with zero transactions costs, bargaining in an unrestricted market leads to optimal economic efficiency. Rottenberg argued that a limitation through a reserve clause would not prevent migration of talent towards major teams. In Coase terms the distribution of resources, in this case player talent, would not be affected by the distribution of ownerships rights. Translation of these theoretical findings to professional sports means that free movement of players will have no effect on their distribution and was defined as the invariance principle (see El Hodiri \& Quirk, 1971).

This North American approach was used as an argument to "prove" that the Bosman case would have no impact on distribution of talent in Europe. Késenne (1998a: 512) argued:

\begin{abstract}
"Along with the North American sports economists, who can look back on an experience of more than twenty years with an open players market, I believe that the abolition of the transfer system in sports is a good thing. There is plenty of scientific evidence on the fact that there is no connection between limitations on players mobility and competitive balance in the leagues." (translation by the authors)
\end{abstract}

The problem was that the European professional team sports environment did not fulfil the main criteria of Rottenberg namely

\footnotetext{
"Markets in which the freedom to buy and to sell is constrained by the reserve rule or by the suggested alternatives to it do not promise better results than do markets constructed on the postulate of freedom. It appears that free markets would give as good aggregate results as any other kind of market for industries, like the baseball industry, in which all firms must be nearly equal if each is to prosper."(Rottenberg, 1956:257)(italics by the authors)
}

Even stronger: Szymanski (2007) recently declared after looking into a number of empirical studies that "this meta-data is hardly a ringing endorsement for the invariance principle, since "no effect" is 
reported in only seven out of twenty MLB studies that he investigated". This means that even in the MLB this theoretical framework can not been fully supported. Today, more than a decade after the introduction of the Bosman case, we notice that the Rottenberg-Coase theorem did not hold for professional team sports in Europe. To underline this argument we will show that from the start on the differences between the European football structure and the MLB indicated that the free agency principle would have enormous consequences for the distribution of players between leagues.

The voices and warnings of sports economists with a more heterodox oriented approach towards the Bosman case such as Downward \& Dawson (2000), Bougheas \& Downward (2003) and Moorhouse $(1999 ; 2002)$ were neglected. Ericson (2000) argued that the source of inefficiency in a free-agency market of football players is created by free riding of large teams on the talent development in the minor teams. This kind of free riding could however be mitigated by the transfer fees for the players at the end of their contract. A fundamental fact that the court did not consider, at least not explicitly, is that football players do not move around in a common market as long as there are independent leagues. This implies that smaller national leagues in particular cannot afford to keep their most talented players in a free-agency market. Consequently, the transfer fee can be motivated as an instrument to stimulate development of talent in small-market teams. Haan, Koning \& Van Witteloostuijn (2002) also warned that free movement of players could be the death penalty for many European leagues. International differences will increase and international competition will become less exciting ${ }^{5}$.

\section{The problem of the North American approach in European football}

\section{Structural differences}

The structural difference between European football leagues and North American professional leagues was not ignored but somewhat neglected. Free agency and the abolishment of limitations on foreign players in a team was introduced in a totally different organised and structured environment. Whilst the labour market became increasingly international in scope, product markets stayed in the first place domestic. In European football, the emphasis is on a primary product market funded by media income and only in the second place on international (European) club competition at the highest levels, also funded by media income (see Downward, e.a., 2009).

The main difference between US and European league structures that have consequences on the relation between labour and product markets are (see in detail Andreff \& Staudohar (2002); Dejonghe \& Troelsen (2006); Dejonghe (2007); Downward, Dejonghe \& Dawson (2009)):

1) There is no significant rival league abroad for the main American professional sports leagues such as the MLB, the National Football League (NFL) and in a lesser degree the National Basketball Association (NBA) and the National Hockey League (NHL). In other words substitution is not a topic. MLB and NFL can be defined as a closed product market because there is no international substitution for them. Until recently, the same could be said for NBA and $\mathrm{NHL}^{6}$. In European football, however, a player can migrate from one league to another. The result is an increasing competition between and within leagues on the labour market. This means that labour and product markets in Europe are different from their American counterparts. Teams are located in a country and have to play in their national competition. Since revenues in European football 
depend mainly on media income, this closed product market is a competitive disadvantage for teams located in smaller markets.

2) Cross-subsidization such as revenue sharing, salary cap and some other measures were introduced in the American system. Teams located in bigger markets share some of their revenues with teams from smaller markets to increase competitive balance in the league. They sometimes even pay a kind of "luxury tax" when their relative or nominal salary rate is too high. The uncertainty of outcome and competitive balance are central issues in US professional team sports. This kind of cross subsidization was the solution proposed by North American oriented sports economists. The European structure of professional football, however, is totally different.

3) US leagues are a closed profit maximizing league of teams granted a territorial monopoly with limitations on franchise numbers and eligibility of the size of a city to host a franchise. In Europe leagues are open and more win maximising oriented. Promotion and relegation in a pyramidal hierarchical structure between leagues in a country on different levels is embedded in the European football tradition. This results in a blocking of cross-subsidization within and between national leagues because it would on the one hand increase the probability of relegation for major teams while on the other hand these major teams are in "need" of high budgets to qualify and have a competitive team for European competitions. There exists, however, some form of revenue sharing when it comes to broadcasting rights in national leagues and marketing revenues in the European Champions League. But even in the Champions League $50 \%$ of the total amount of money is divided according to the market size of the countries where clubs are located.

4) Migration, tax and other laws in Europe are different from country to country. This results sometimes in competitive advantages created by local, regional and national authorities.

\section{Changes in the labour market}

North American oriented sports economists argued that Europe had to transform its competition structure towards the so called "ideal" US model. In reality a shift in market power occurred. Teams lost their monopsony position, and as outlined in figure 1, many players became monopolists.

\begin{tabular}{|c|c|c|}
\hline $\begin{array}{c}\text { Team Powerl } \\
\text { Player Power }\end{array}$ & LOW & HIGH \\
\hline HIGH & $\begin{array}{c}\text { Monopoly: } \\
\text { 'Star Model' }\end{array}$ & $\begin{array}{c}\text { Bilateral Monopoly: } \\
\text { 'Bargaining over } \\
\text { rents' }\end{array}$ \\
\hline LOW & $\begin{array}{c}\text { Perfect Competition: } \\
\text { 'Just Wage' }\end{array}$ & $\begin{array}{c}\text { Monopsony: } \\
\text { Exploitation of } \\
\text { Players }\end{array}$ \\
\hline
\end{tabular}

Figure 1: Labour market structures in professional team sports (Downward \& Dawson,2000: 187)

The shift of bargaining power from clubs towards players resulted in an increasing competition to attract the best player talents. Win maximizing teams lost their power and ended up with financial problems because of an inter and intra league competition combined with policies aiming at short term success. The reason is that according to Dawson \& Downward (2000) and Késenne (2002) teams in a win maximizing environment will overpay their players, with potential adverse implications that may explain some of the financial problems in European football. Football in Europe evolved from 
somewhat profit maximising national monopsony leagues towards a set of win-maximising leagues that operate in a unified open player talent market (Downward e.a., 2009).

Because there was not any foreign competitive competition for major US leagues, the combination of profit maximizing clubs in a closed labour market with a fixed number of talents in a closed product market results, according to Quirk \& Fort (1992), into a Walrasian equilibrium. The opening of the European open labour market made the number of talents variable. This means an increasing competition between clubs to stay competitive within their league and at the European level between clubs of different leagues. In this setting, strategic interaction at the labour market occurs, so a game theoretical approach applies.

\section{Changes in the product market}

In win maximizing European leagues all teams try to maximize their performance on the pitch. Under these conditions teams with higher budgets hire more and better players to increase their probability to win. Increasing competitiveness within and between leagues results in a "foot drain" of player talent towards the main leagues (Darby (2001); Van de Moortele (2003); Dejonghe (2004); Poli \& Ravenel $(2006 ; 2008))$.

The main variable that gives long term assurance of sports successes is the total turnover of the club (see Van der Werf \& Verlaan (1994), Szymanski \& Kuypers (1999), Dobson \& Goddard (2001), Hall, Szymanski \& Zimbalist (2002), Dejonghe (2004;2007), Deloitte (2005;2006;2007;2008), Dejonghe \& Vandeweghe (2006)). Turnover of a club/league is related to income sources. Until the nineties the financial structure of professional football was what Andreff \& Staudohar (2002) referred to as the traditional Spectator-Subsidies-Sponsors-Local or SSSL-model. The main sources of revenues of the clubs were ticketing, local subsidies and local sponsors. The changing structure and environment of European professional football forced major clubs and leagues to change their structures to a more encompassing Media-Corporations-Merchandising-Markets-Global model (MCMMG-model). The clubs and leagues became a broader economic product with broadcasting rights and sponsorship as the main sources of income ${ }^{7}$. Deloitte (2008) estimated the market size of European football in 2007 on $€ 13.6$ billion. The turnover of Big 5 European leagues tripled since 1995/96 and represent $€ 7.1$ billion or $52 \%$ of this amount. The newly signed media contract of $€ 4.2$ billion for the period 2007/08-2009/10 in the English Premier League shows that the market power of this league will increase. This results probably in a domination of the Premier League towards other leagues of the Big 5. Smaller but historical successful leagues such as Belgium, The Netherlands, Portugal and Scotland have a comparative disadvantage, because total turnover of these leagues amounts only to $€ 1.17$ billion.

The result was that clubs located in bigger product markets, read broadcasting markets, had a comparative advantage over clubs located in smaller product markets. Competition between European teams transformed from team level towards league level and resulted, as predicted theoretically by Haan, Koning \& Van Witteloostuijn (2002), in a gradually decreasing role for historical major teams such as Ajax Amsterdam, RSC Anderlecht, Celtic Glasgow and FC Porto, to mention some in European competitions. Competition between closed product markets in a win maximizing environment resulted after 1995 in an increasing domination of clubs from the big markets in Spain, Italy, England and in a far lesser degree Germany and France. 
In the latest years, divergence of broadcasting revenues increased between Big 5 leagues and other leagues because of a restructuring of the Champions League market pool. From 1991, when the Champions League was created, until 1999 UEFA divided 75\% of their Champions League marketing revenues according to performances on the pitch. This implied that the remuneration for a victory, tie or loss was independent of the country of a team. In 1999 the Big 5 demanded (and obtained) another system of Champions League revenue sharing. From 1999 on the distribution system changed the share that went to the 32 teams participating at the Champions League. Since then, a share of $50 \%$ (of this $75 \%$ ) is being distributed according to the value of each TV market represented by the participating teams. Needless to say that this modification favoured teams from bigger markets (the Big 5). Introducing this market pool was forced by the major leagues. UEFA was anxious that major teams would create an alternative European Football League $(E F L)^{8}$ sponsored by media groups. As a result financial divergence between Big 5 and other leagues increased and the only minor form of revenue sharing was partly eliminated.

In sum, recent modifications in the product market have lead to a transformation of the competition structure between the Big 5 and the rest of the leagues towards a Stackelberg equilibrium. Clubs from the Big 5 are market leaders that have the greatest market power and attract in a win maximizing environment the best player talents. On the long term this will end in a concentration of player talents and an increase in win percentages of teams from the Big 5 when they play against teams from other competitions. Leagues in smaller markets such as The Netherlands, Belgium, Scotland and Portugal moved gradually towards a secondary position in Europe. Their major teams could or can in some degree still compete on a level just below that of teams of the Big 5. These leagues transformed themselves into "stepping stone" leagues or "minor" leagues where player talents are "educated" and sold to teams of the major leagues (Dejonghe,2007).

\section{Empirical verification of the concentration of player talent and performance in European competitions}

\section{Migration and concentration of player talent towards Big 5 leagues}

In this section, we look at empirical evidence on the concentration of player talent and the divergence in performance in win maximizing European competitions in the Big 5. To do so we use in a first step a descriptive method and compare the league of players at the US World Cup 1994 and the Germany World Cup 2006. World Cup 94 took place before the Bosman case opened the labour market in EU professional football. Data on national teams at these World Cups were found on the internet ${ }^{9}$. We select World Cup squads because at this tournament the best national teams of Europe and the rest of the world are competing each other. At World Cup 94, 24 countries were represented with each 22 players while in 2006, 32 countries participated with each 23 players.

To analyze foot drain or migration of talents towards the biggest leagues it is necessary to take some socio-economic and historical characteristics into account. Lanfranchi \& Taylor (2001), Van De Moortele (2003) and Dejonghe (2004a;2004b) notice some historically determined migration patterns. According to their findings foot drain is mainly concentrated between European Leagues on the one hand and stemming from South America, former English and French colonies in Central America, Africa and Australia on the other hand. Players from Asia and Spanish speaking Central America have 
competitive salaries in their own national leagues. High wages in their national leagues of lower quality are a barrier for players mobility towards Europe. Migration from these countries is a rather recent phenomenon and had low significance until today.

The total number of players at World Cup 94 was 528. Saudi Arabia and South Korea represented Asia and only one of their 44 selected players was a member of a European team. Spanish speaking Central America had Mexico as participant and only two of their squad played in Spain. Eliminating these countries from our dataset indicates that the number of players we will look at is reduced to 462 . For World Cup 2006, 736 players were involved. Mexico and Costa Rica represented Spanish speaking Central America while Japan, South Korea, Saudi Arabia and Iran represented Asia. Saudi Arabia had no players in European competitions, Costa Rica one, Mexico two, Iran and Japan five and South Korea six. We notice here already some opening towards new migration patterns but in comparison with European, African and some South American countries they are still more closed. Eliminating these leagues reduces our dataset to 598 players.

When looking at the number of players participating at World Cups that are member of a club in the Big 5 and in stepping stone leagues such as The Netherlands, Portugal, Belgium and Scotland, we see evidence of what has been predicted theoretically. The number of talents playing in Big 5 leagues increased dramatically between 1994 and 2006. When we make a distinction between talents playing in the league of their own country and immigrated players from other countries (see figure 2), we notice that this increase stems almost entirely from the increase in immigrant players in these countries. In stepping stone leagues we observe no significant impact.

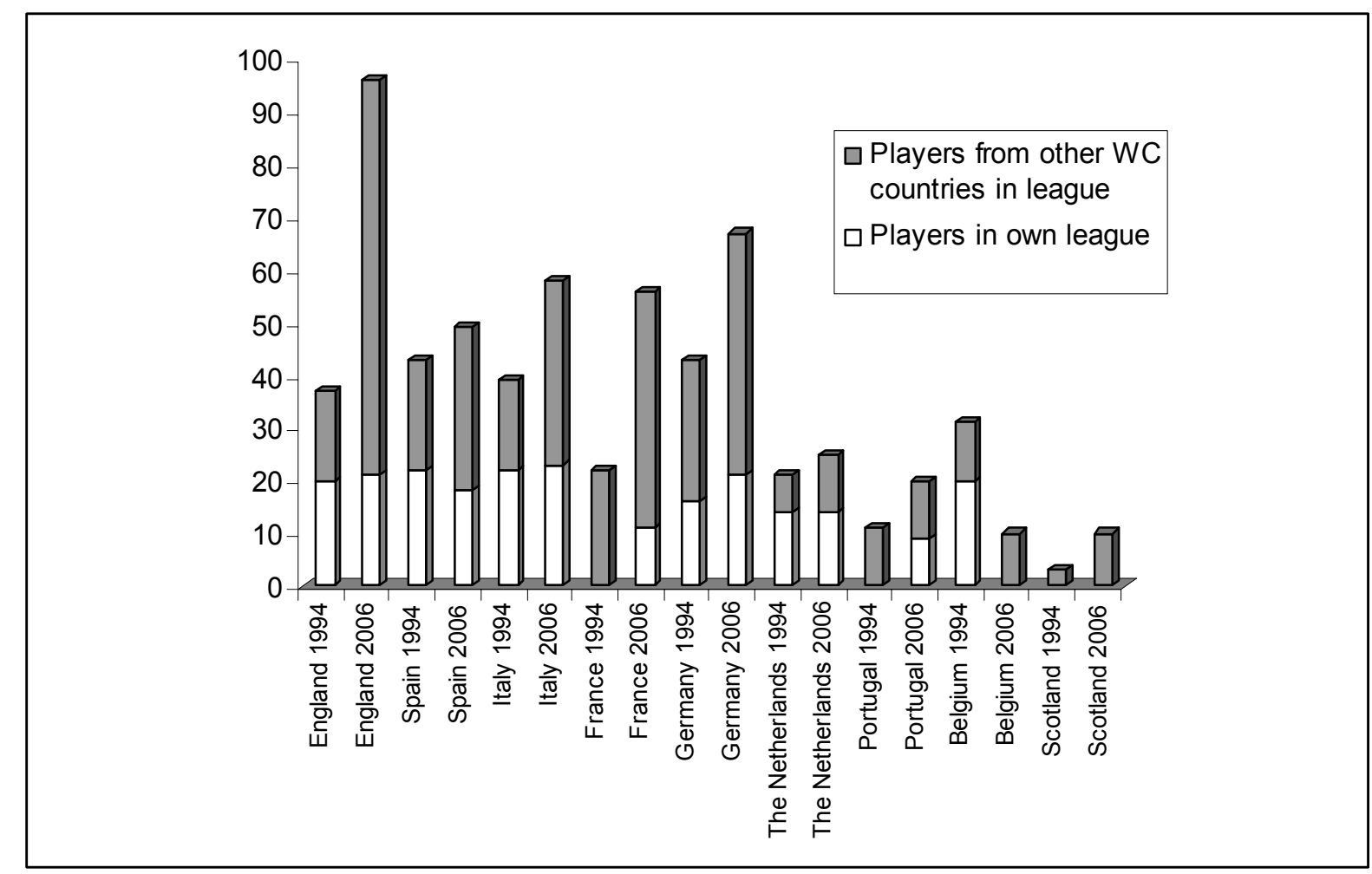

Figure 2: Number of players at World Cups $(1994,2006)$ playing in Big 5 and stepping stone leagues * France and Portugal were not qualified for World Cup 1994, Belgium not for 2006 and Scotland not for both tournaments.

The increase in Big 5 leagues is not only caused by the increasing number of players in the dataset. Looking at relative values, we see that, in $1994,39.8 \%$ of the selected players played in Big 5 
leagues, compared to $54.6 \%$ in 2006 . In stepping stone leagues we noticed a decrease from $14.2 \%$ to $10.9 \%$. These figures could be influenced by players performing in their own league. Eliminating those players gives us an indicator of player migration towards these leagues. In 1994,94 or $20.3 \%$ of the selected players at the World Cup were players that migrated towards a team from the Big 5. In 2006 this figure was already 232 or $38.8 \%$. In the same period we notice a stagnation in stepping stone leagues from $32(6.9 \%)$ to $42(7.0 \%)$.

These data show an evolution towards a concentration of talents in Big 5 leagues and even more specific a potential dominance in the future of the Premier League (England). Using other data, Poli \& Ravenel (2008) analyzed the percentage of players that played at least once for their national team. In 2007/08, the Big 5 average of this percentage was $45.0 \%$ with $66.2 \%$ for the Premier League. To name yet another figure, in 2007/08, the percentage of full internationals in top 5 clubs of each league from the Big 5 was $64.6 \%$. On the other hand, the increasing migration and number of foreign players in stepping stone leagues is not an sufficient condition for a structural quality improvement of these leagues. Players migrating towards these leagues are in some cases not talented enough to be selected for Big 5 leagues or use these leagues as a stepping stone to success.

\section{Divergence of sports success between the Big 5 and the rest of the leagues}

The increasing concentration of player talent is a result of an open labour market in EU. In a next step we will show empirical evidence that this kind of concentration in a closed product market results in an increasing sports success of teams from major leagues. To do this, we use the UEFA country ranking of UEFA national football federations. Despite its name, this is not a ranking, but an index of the performance of teams from a country in European Cups during the last five seasons ${ }^{10}$. We make use of the UEFA country ranking in 1995, the last season before the Bosman case, and the most recent ranking from 2008.

In order to evaluate the impact of the Bosman case, we compare the position of Big 5 leagues between 1995 and 2008 with respect to this variable. While we want to control for market size, we apply multiple regression to evaluate this position, which allows us to evaluate the position of some other special cases as well.

This results in the following regression equation:

UEFA country ranking ${ }_{i}=\beta_{0}+\beta_{1}$ BIG $_{i}+\beta_{2}$ STEPPINGSTONE $_{i}+\beta_{3}$ OLIGARCH $_{i}+\beta_{4} \operatorname{Ln}\left(\right.$ GDP $\left./ C A P I T A_{i}\right)$ $+\beta_{5} \operatorname{Ln}($ POPULATION $)+\varepsilon_{i}$

where $\mathrm{i}$ indexes each country.

The dependent variable, the UEFA country ranking, existed in 1995 out of 47 federations and in 2008 out of 53 federations. Montenegro, however, is a member of UEFA for less than five years, so we use 52 observations for 2008.

Some leagues have specific characteristics with respect to broadcasting rights, one of the main revenue resources in professional football. In Big 5 leagues, these broadcasting rights are extremely important and give teams of these leagues a competitive advantage over other leagues in Europe, as 
discussed in previous sections. The problem is that these data are not available for all federations. Therefore, we use dummy variables. We expect a significant increase in the coefficient of the BIG 5 dummy between 1995 and 2008. Another dummy, STEPPINGSTONE, indicates The Netherlands, Portugal, Belgium and Scotland, which we denoted in previous sections as stepping stone leagues. These countries are historical top countries in European competitions but moved gradually towards a secondary position. We expect the coefficient of this dummy to be positive because of the historical strong performance of these countries. Therefore, these countries have relative high broadcasting rights both in 1995 and 2008 in comparison with other non Big 5 countries. OLIGARCH is a dummy that indicates alternative financing by local oligarchs in some former Communist countries. More specifically, this dummy indicates Ukraine, Russia, Bulgaria and Romania. We predict a non significant relation with the dependent variable in 1995 and a positive significant impact of this dummy variable in 2008.

While our focus is on the relative performance of these three groups, indicated by dummy variables, we want to control for market size as well. This allows us to evaluate the impact of the opening of the labour market on these leagues ceteris paribus the role of market size. We capture market size by the natural log of gross domestic product per capita and by the natural log of population size, indicated by variables Ln (GDP/CAPITA) and Ln (POPULATION). While both variables are an indicator of potential revenues for teams, sponsors and media, population captures the pool for home grown talent as well. We expect that both variables will have a significant positive impact on the UEFA country ranking.

\begin{tabular}{|l|c|c|}
\hline \multicolumn{2}{|l|}{ Dependent variable: UEFA country ranking (1995, 2008) } \\
\hline Independent variable & $\mathbf{1 9 9 5}$ & $\mathbf{2 0 0 8}$ \\
\hline BIG 5 & $22.4070^{\star * *}$ & $40.4367^{* * *}$ \\
& $(5.1035)$ & $(6.2799)$ \\
STEPPINGSTONE & $10.8481^{* * *}$ & $18.1760^{\star * *}$ \\
& $(3.7053)$ & $(3.4367)$ \\
OLIGARCH & 2.1537 & $18.8076^{* * *}$ \\
& $(2.2258)$ & $(3.5955)$ \\
Ln (GDP/CAPITA) & $2.7546^{* * *}$ & $4.2036^{* * *}$ \\
& $(0.4903)$ & $(1.1631)$ \\
Ln (POPULATION) & $3.6195^{\star * *}$ & $3.2953^{\star * *}$ \\
& $(0.6032)$ & $(0.6159)$ \\
Constant & $-19.0765^{* * *}$ & $-34.8672^{* * *}$ \\
& $(4.3887)$ & $(11.3179)$ \\
\hline $\mathrm{n}$ & 47 & 52 \\
$\mathrm{R}^{2}$ & 0.8568 & 0.8805 \\
\hline
\end{tabular}

Table 1: Regression estimates (OLS, Huber-White-sandwich standard errors between brackets) ${ }^{*} p<0.1,{ }^{* *} p<0.05,{ }^{* * *} p<0.01$

The results in table 1 show an increasing positive coefficient for all dummy variables, where the increase is the most significant for the BIG 5 and the OLIGARCH dummies ${ }^{11}$. Controlling for market size, we see, as expected, that BIG 5 leagues have a disproportional high, and increasing impact on UEFA country ranking. Also STEPPINGSTONE leagues have a score that is significantly higher than the other leagues, both in 1995 and 2008. This can be explained by their strong historical position, combined with the fact that some of their clubs enjoy Champions League market pool revenues as 
well, albeit only marginally compared to clubs from BIG 5 leagues. As expected, the OLIGARCH dummy proved not to be significant in 1995, while its coefficient increased significantly in 2008. While the coefficients of Ln (GDP/CAPITA) and Ln (POPULATION) appear to be significant for both years, no significant increase in these coefficients occurs. This means that the theoretically expected increase in importance of market size in explaining the UEFA country ranking after the opening of the labour market, is almost entirely skimmed by BIG 5 leagues.

Another method to find evidence on an increased concentration at the top is to look at the final stages of the UEFA Champions League. We compare the origin of 64 teams qualified for the quarter final for the periods 1991/92-1998/99 and 1999/2000-2006/07. 1991/92 was the first year of the contemporary structure of UEFA Champions League and 1998/99 was the last season before the above mentioned market pool was introduced. Figure 3 shows us the concentration of football success in most of the Big 5 leagues. Spain, England and Italy noticed a significant increase of teams qualified for the UEFA Champions League quarter finale, while German and French teams became less successful. Teams from stepping stone leagues, from former USSR countries, and other leagues faced a decreasing prospect for qualification.

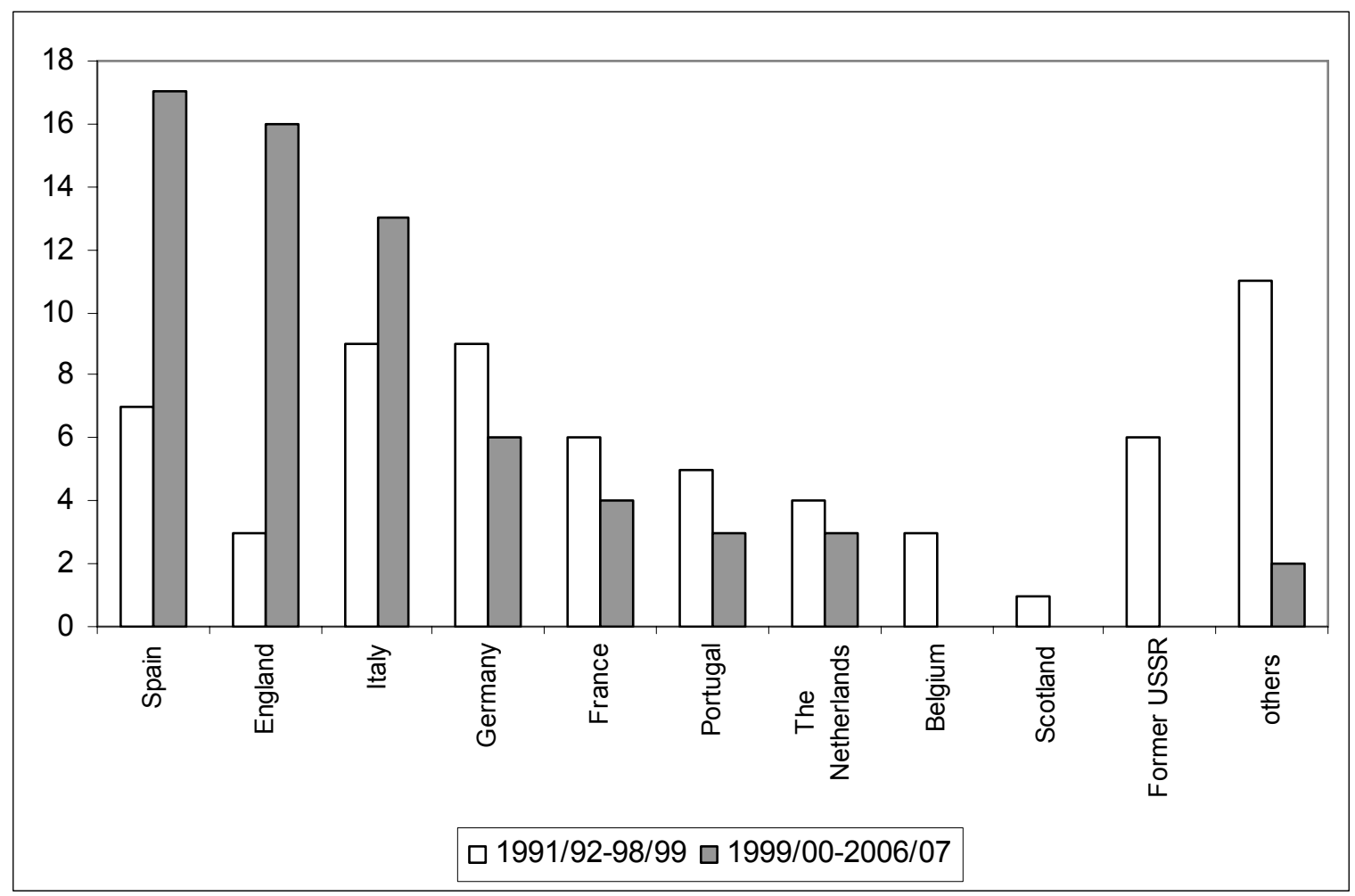

Figure 3: Number of teams per country qualified for quarter finals in the Champions League 1991/92$1998 / 99$ and 1999/2000-2006/07

An explanation for the divergence between the Big 5 leagues can be found when looking at figures on their turnover and wage costs. Data from Deloitte (2008) shows us that total wage costs in 2006/07 in England was $€ 1.440$ billion, compared to $€ 822$ million in Spain, $€ 722$ million in Italy, $€ 620$ million in Germany and $€ 619$ million in France. In 1995/96 this was only €256 million in England and Italy, €187 million in Germany, $€ 175$ million in Spain and $€ 161$ million in France. 


\section{Conclusion and future options}

The Bosman case created an open labour market in a closed product market in a win maximization environment. This situation was total different than the American open labour market in profit maximizing leagues with no international competitors. At first, many sports economists adhered to the American approach towards professional team sports and argued that opening the labour market would have no effect on the distribution of talent. Despite early warnings by other scholars in sports economics, European football can not been compared with American leagues. They predicted a concentration of talent when teams have to compete first in their own league to qualify for European competitions. Besides the intra league competition, inter league competition became also important.

The strong relation between turnover and sports success made that major product markets gradually monopolized revenues so that they could attract better talents. Therefore, inter league competition is linked with the market size of national competitions. As a result Big 5 leagues evolved towards a near monopolisation of European success. To express it in game theoretical terms, Big 5 leagues moved to a leader position in a Stackelberg equilibrium. Stepping stone leagues and the other leagues were moved into a followers position and noticed decreasing sports successes.

Empirical data of World Cup 1994 and World Cup 2006 showed us that after the Bosman case a concentration of talent in Big 5 occurred. This concentration resulted in improving sports successes of Big 5 leagues. Next to this, we see an increase in the sports successes of (recently) oligarchic funded leagues such as Russia, Ukraine, Romania and Bulgaria, and of stepping stone leagues. Inside the Big 5 we notice a divergence between Spain-England-Italy and Germany-France that may be related to a divergence in their wage costs.

The main reason for this divergence is the opening of the labour market with migrating players in a closed win maximizing product market with almost no revenue sharing. Some sports economists see a solution in an further Americanisation of European football, resulting in a European Major League Football that resembles the European Football League format of 1998, with one of more semi closed divisions and forms of cross subsidization such as salary cap and revenue sharing. According to them this evolution is inevitable as this would reduce the gap between major and smaller leagues (see Késenne, 1998b,2007; Hoehn \& Szymanski,1999; Szymanski \& Kuypers,1999; Noll,1999; Dobson \& Goddarsd,2001; Durand e.a.,2005; Lago e.a.,2006; Baroncelli \& Lago,2006). From an economic viewpoint creating an European Major League Football would be the natural outcome of the transformation of locally embedded football into a more business and media oriented entertainment.

This idea, however, stands in opposite of European football culture and would create a heavy debate. Bale (1996) and Dejonghe (2001) already mentioned the importance of strong relations with local communities, called "topophilia", and the existence of historical traditions and rivalries in every country. Dobson \& Goddard (2001) also notice that those in favour of a total withdrawal of major teams from their domestic league underestimate the importance of domestic history and tradition as typical characteristics of football identity in Europe. Arnaud (2006) refers also to the tradition of the football fan who wants a "twin-pillar" structure consistent of a national competition and an European competition. 
Instead of an Americanisation we address some other solutions. On the one side we can open the product market to some degree by creating some regional leagues or we could close the labour market to a certain degree. The first solution, opening the product market by the creation of regional leagues, has been proposed already by smaller leagues themselves. In 1998, some major teams ${ }^{12}$ from the stepping stone leagues tried to create an Atlantic League (later on Euro League, including teams from Norway, Denmark and Sweden as well). The aim of this regional league was to strengthen the financial position of their clubs through broadcasting rights while holding their traditional and historical position in a European context. They believed in a transnational league of big clubs from smaller leagues so that they could compete with teams from the Big 5. UEFA, however, rejected this proposal and argued that the Bosman case had no effect on competitive balance and that national leagues are a defining characteristic of the European sports structure. In this system the product market would have been semi-open. The number of leagues in Europe would decrease and the financial gap with the Big 5 would decrease. Another example of regionalisation of leagues is the idea of a "Bene League", combining the best teams of Belgium and The Netherlands. This "phantom" appears occasionally in the media or in debates but has never been taken serious. A "Bene-league", however, would take concerns of local embedment and identity better into account than the geographically and culturally hybrid concept of an "Euro League".

Closing the labour market to some degree means a limitation on the number of foreign players in national leagues. In the last years some new attempts to restrict players mobility, such as compensation systems of youth players and $6+5$ or home grown rules, were launched. FIFA advocates the $6+5$ rule, which basically states that a team must start with at least six players that should be eligible for the national team of the country in which the club is located. The chairman of FIFA, Sepp Blatter, argued recently at a FIFA congress that hiring an increasing number of foreign players results in a loss of the local, regional en even national identity of clubs (FIFA,2008). Young players lose, according to Blatter, their motivation to practice and rich clubs brought a two-tier competition in many countries with only a few teams with a lot of foreign talents playing for the title. Blatter wanted to convince the EU to refer to the specificity of sports in the new European Treaty. With this rule FIFA opposed the UEFA home grown rule, which sets a quota of locally-trained players without discrimination on grounds of nationality. Blatter's proposal, however, is unworkable in the EU because it contravenes EU laws on the free movement of labour and creates a direct discrimination based on nationality. The European Parliament voted against the $6+5$ rule in a resolution adopted on May $8^{\text {th }}$ 2008. The home grown rule on the other hand, where clubs are obliged to have a certain number of during three years locally-trained players between the age of 15 and 21 years, does not imply discrimination based on nationality. It only protects locally trained players and was supported by European Parliament. This rule would ensure investments in grass roots youth development. Some sports economists, however, declare that introducing these labour market limitations would result in a return to the Pre Bosman era. As could be expected, some English clubs from the Premier League protested against this rule as well. FC Liverpool manager Rafael Benitez criticised this rule and argued that you need the best players you have on the pitch when you are competing in the Champions League (Fay,2008). This free market argument is typical for dominant players in an economic environment.

Sports economists have been defining both Walrasian and Nash equilibria for several labour/product market combinations. We plead, however, to enrich these textbook neoclassical analyses with non tangible issues such as local embedment and identity. The European White Paper on Sport recognized the specificity of sports and argued that an open product market is not institutionalized in 
the European way of looking at professional football. The problems with an open labour market, which creates a concentration of player talent into some leagues and teams stimulated the EU to recognize sports as something specific. As a result, European professional football shall probably evolve towards a closed product market with limitations on the openness of the labour market.

\section{References}

Andreff, W. and Staudohar, P., 2002, European and US sports business models, in Barros, Ibrahimo and Szymanski, eds., Transatlantic sport: the comparative economics of North American and European sports (Edward Elgar Pub, Northampton), 23-49.

Arnaud, J.-L., 2006, Independent European sport review, EU.

Associated Press, 2007, The Premier League negotiates new overseas TV deal (The Associated Press) $18 / 01 / 2007$

Bale, J., 1996, Space, place and body culture: Yi-Fu Tuan and a geography of sport, Geografiska Annaler, 78B, 3, 163-171.

Baroncelli, A., and Lago, U., 2006, Italian football, Journal of Sports Economics, 7, 13-28.

Bougheas, S., and Downward, P., 2003, The economics of professional sports leagues: some insights on the reform of transfer markets, Journal of Sports Economics, 2, 87-107.

Coase, R., 1960, The problem of social cost, Journal of Law and Economics, 3, 1-44.

Darby, P., 2001, The new scramble for Africa: African football migration to Europe, in Mangan, J., ed., Europe, sport, world: shaping global societies (Frank Cass, London), 217-244.

Dejonghe, T., 2001, Sport in de wereld: ontstaan, evolutie en verspreiding (Academia Press, Gent).

Dejonghe, T., 2004a, Sport en economie: een noodzaak tot symbiose (Arko Sportsmedia, Nieuwegein).

Dejonghe, T., 2004b, Football in Belgium: from centre to semi-periphery: analyzing the financial ground, paper presented at the $7^{\text {th }}$ IASE congress, Ottawa, 18-21 juni 2005, 15p.

Dejonghe, T., 2007, Sport en economie; een aftrap (Arko Sports Media, Nieuwegein).

Dejonghe, T. and Troelsen, T., 2006, The need of competitive balance in European professional soccer: A lesson to be learned from the North American Professional leagues, in Papanikos, G., ed., An amalgam of sports and exercise research (Atiner, Piraeus), 35-54.

Dejonghe, T. and Vandeweghe, H., 2006, Belgian football, Journal of Sports Economics, 7, 105-113.

Deloitte, 2005;2006;2007;2008, Annual review of football finance, (Deloitte and Touche and Tohmasu, Manchester).

Dobson, S. and Goddard, J., 2001, The economics of football (Cambridge University Press, Cambridge).

Downward, P. and Dawson, A., 2000, The economics of professional team sports (Routledge, London).

Downward, P., Dawson, A. and Dejonghe, T., 2009 (forthcoming), Economics of sport: theory, evidence and policy, Oxford, Butterworth-Heinemann.

Durand, C., Ravenel, L. and Bayle, E., 2005, The strategic and political consequences of using demographic criteria for the organisation of European Leagues, European Journal of Sport Science, 5, 167-180.

El Hodiri, M. and Quirk, J., 1971, An economic model of a professional sports league, Journal of Political Economy, 79 , 1320-1319.

Ericson, T., 2000, The Bosman case. Effects of the abolition of the transfer fee, Journal of Sports Economics, 1, 203-218.

Fay, S., 2008, Champions League - Benitez slams new rule, Eurosport, 10/09/2008, http://uk.eurosport.yahoo.com/10092008/58/champions-league-benitez-slams-new-rule.html.

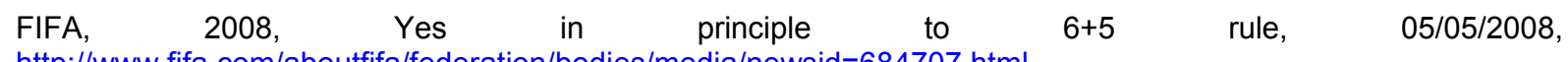
http://www.fifa.com/aboutfifa/federation/bodies/media/newsid=684707.html,

Haan, M., Koning, R. and Van Witteloostuijn, A., 2002, Market forces in European soccer, Universiteit Groningen, SOM Research Reports 02F18. 
Hall, S., Szymanski, S. and Zimbalist, A., 2002, Testing causality between team performance and payroll. The cases of Major League Baseball and English soccer, Journal of Sports Economics, 3, 149-168.

Hoehn, T. and Szymanski, S., 1999, European football: the structure of leagues and revenue sharing, Economic Policy, 204-240.

Késenne, S., 1998a, De aangekondigde dood van het Belgische voetbal, Streven, 65, 511-519.

Késenne, S., 1998b, Opbrengstendeling en marktregulering in professionele ploegsporten, Economisch en Sociaal Tijdschrift, 52, 35-49.

Késenne, S., 2002, The monopsonistic player market in a win-maximising league, European Sport Management Quarterly, 2, 180-187.

Késenne, S., 2007, The Peculiar International Economics of Professional Football in Europe, Scottish Journal of Political Economy, 54, 388-399.

Lago, U., Simmons, R. and Szymanski, S., 2006, The financial crisis in European football, Journal of Sports Economics, 7, 3-12.

Lanfranchi, P. and Taylor, M., 2001, Moving with the ball: the migration of professional footballers (Berg, Oxford).

Moorhouse, H., 1999, Football post Bosman: the real issues in Jeanrenaud, C. and Késenne, S., eds., Competition policy in professional sport: Europe after the Bosman case (Standaard Uitgeverij, Antwerp), 161-180.

Moorhouse, H., 2002, The distribution of income in European football: big clubs, small countries, major problems, in Barros, Ibrahimo and Szymanski, eds., Transatlantic sport: the comparative economics of North American and European Sports (Edward Elgar Pub, Cheltenham) 69-108.

Noll, R., 1974, Government and the sport business (Brooking Institution, Washington).

Noll R., 1999, Competition policy in professional sports after the Bosman case, in Jeanrenaud, C. and Késenne, S., eds., Competition policy in professional sport: Europe after the Bosman case (Standaard Uitgeverij, Antwerp), 17-44.

Parrish, R. and McArdle, D., 2004, Beyond Bosman: The European Union's influence upon professional athletes' freedom of movement, Soccer and Society, 7, 403-419.

Paternoster, R., Brame, R., Mazerolle, P. and Puquero, A., 1998, Using the Correct Statistical Test for the Equality of Regression Coefficients, Criminology, 36, 859-866.

Poli, R. and Ravenel, L., 2008, Annual review of the European players' labour market (Editions CIES-CERSOT, Neuchâtel).

Quirk, J. and Fort, R., 1992, Pay dirt: the business of professional team sports (Princeton University Press, Princeton NJ).

Rottenberg, S., 1956, The baseball player's labour market, Journal of Political Economy, 64, 242-258.

Scully, G., 1989, The Business of Major League Baseball (Chicago University Press, Chicago).

Szymanski, S., 2007, The champions league and the Coase theorem, Scottish Journal of Political Economy, 54, 355-373.

Szymanski, S. and Kuypers, T., 1999, Winners and losers, the business strategy of football (Penguin Books, London).

UEFA European Cup Football, 2008, www.xs4all.nl/ kassiesa/bert/uefa, 02/10/2008,

Van den Bogaert, S.,2005, Practical Regulation of the Mobility of Sportsmen in the EU Post Bosman (Kluwer Law International, The Hague).

Van de Moortele, K., 2003, De migraties van profspelers in de voetbalwereld, De Aardrijkskunde, 2003, 3/4, 7986.

Van der Werff, R. and Verlaan, K., 1994, Professioneel voetbal in Europa: een economisch-geografische analyse, Proefschrift geografie (Universiteit Utrecht, Utrecht).

Notes

${ }^{1}$ Corresponding author. Trudo Dejonghe, PhD. Department of Business Studies, Lessius University College, Korte Nieuwstraat 33, 2000 Antwerp, Belgium. Phone: 0032 (0) 3 / 201.18.15, trudo.dejonghe@lessius.eu

${ }^{2}$ The authors wish to thank Bart Capéau, Steven Groenez and Maxime Loose for their helpful comments and Dirk Van Massenhove for editorial assistance. Any remaining errors belong to the authors. 
${ }^{3}$ Competitive balance refers to balance between sporting strength of teams in a league. The more balanced they are, the more uncertain the outcome of each match and the more fans should be interested. Empirical verification of this view point is, however, not straight forward (See Downward e.a.,2009).

${ }^{4}$ Article 39 (ex Article 48) 1. Freedom of movement for workers shall be secured within the Community. 2. Such freedom of movement shall entail the abolition of any discrimination based on nationality between workers of the Member States as regards employment, remuneration and other conditions of work and employment. 3. It shall entail the right, subject to limitations justified on grounds of public policy, public security or public health: (a) to accept offers of employment actually made; (b) to move freely within the territory of Member States for this purpose; (c) to stay in a Member State for the purpose of employment in accordance with the provisions governing the employment of nationals of that State laid down by law, regulation or administrative action; (d) to remain in the territory of a Member State after having been employed in that State, subject to conditions which shall be embodied in implementing regulations to be drawn up by the Commission (Van den Bogaert(2005).

${ }^{5}$ Later on, neoclassical oriented sports economics created a framework that explained the divergence between leagues in a win maximizing environment (e.g. Késenne, 2007). Unfortunately, these arguments have not been developed before the Bosman case was implemented.

${ }^{6}$ Only recently some European countries such as Russia (ice hockey), Greece and Spain (basketball) started to become competitors.

${ }^{7}$ In 1983 the BBC paid £2.6 million to cover the league on television In 2005/06 the total turnover of the English Premier League stood at $€ 1.974$ billion with $€ 839$ million from broadcasting rights, $€ 655$ million from match day revenues and $€ 500$ million from sponsoring according to Deloitte (2007). In a recent broadcasting deal for the period 2007-2010 Sky is paying $£ 1.314$ billion, Setanta $£ 392$ million, foreign broadcasting rights $£ 625$ million and internet and mobile telephone providers $£ 400$ million or $£ 910.33$ million a year. The total turnover of the Premier League in 2007/08 is estimated on €2.555 billion (The Associated Press,2007; Deloitte,2007).

${ }^{8}$ Media Partners wanted to create this league in 1998. Their idea was a closed revenue sharing league with 16 or 32 teams. Arsenal, Manchester United, Liverpool, Juventus, Inter Milan, AC Milan, Bayern München, Borussia Dortmund, Panathinaikos, Galatasaray, Benfica, Paris St Germain, Marseille, Ajax Amsterdam, Real Madrid and FC Barcelona would play in the closed highest division of EFL. The second division consisted out of teams that qualified themselves by performing well in their national competition. Rupert Murdoch, Leo Kirch, Silvio Berlusconi and AI Waleed Bin Talal were the potential investors and JP Morgan Bank, Slaughter \& May and Media Partners would manage the competition.

9 http://www.planetworldcup.com/CUPS/1994/wc94squads.html and http://www.planetworldcup.com/CUPS/2006/wc06squads.html

${ }^{10}$ In those five years each team gets two points for a win and one point for a draw. Points in qualification matches are halved: one point for a win and half a point for a draw. One bonus point is allocated for reaching the quarter final, the semi final and the final. Reaching the group stage of the Champions League yields 4 bonus points (from 2005-2009: 3 points). And also qualification for the first knock-out round of the Champions League yields 1 bonus points. The so-called UEFA coefficients are calculated by taking an average, based on the total number of points divided by the total number of teams of each country. The UEFA country ranking is computed by the sum of 5 coefficients in the last 5 years.

${ }^{11}$ In order to test for the equality of regression coefficients, we applied a z-test, as proposed by Paternoster et al. (1998).

12 Ajax, Feyenoord and PSV (The Netherlands), RSC Anderlecht (Belgium), Celtic and Glasgow Rangers (Scotland) and FC Porto and Benfica (Portugal). 